\title{
Efficacy and tolerability of lanreotide Autogel therapy in acromegalic patients previously treated with octreotide LAR
}

\author{
O Alexopoulou, P Abrams ${ }^{1}$, J Verhelst ${ }^{2}$, K Poppe ${ }^{3}$, B Velkeniers ${ }^{3}, \mathrm{R} \mathrm{Abs}^{1}$ and D Maiter \\ Department of Endocrinology, UCL-St Luc Hospital, Brussels, Belgium, ${ }^{1}$ Department of Endocrinology, University Hospital of Antwerp and Antwerp \\ Metabolic Research Unit (AMRU), Antwerp, Belgium, ${ }^{2}$ Department of Endocrinology, Middelheim Hospital, Antwerp, Belgium and ${ }^{3}$ Department of \\ Endocrinology AZ-VUB Hospital, Brussels, Belgium
}

(Correspondence should be addressed to O Alexopoulou, Service d'Endocrinologie et Nutrition, Cliniques Universitaires St Luc, Avenue Hippocrate 54, UCL 54.74, B-1200 Brussels, Belgium; Email: orsalia.alexopoulou@diab.ucl.ac.be)

\begin{abstract}
Objective: This open label, multicentre study was designed to evaluate the efficacy and tolerability of lanreotide Autogel (L-Autogel) in acromegalic patients over a 24-week period. The outcome of treatment with this new, long-acting, aqueous formulation of lanreotide was also compared with the patients' previous treatment with octreotide long acting repeatable (LAR).

Design and methods: Twenty-five acromegalic patients (13 males, mean age $51 \pm 12$ years) were switched from octreotide LAR $(20-40 \mathrm{mg} / 4$ weeks for at least 6 months) to L-Autogel, given deep subcutaneously at a fixed dose of $90 \mathrm{mg} / 4$ weeks. After 12 weeks, the dose of L-Autogel was titrated according to patients' mean GH and IGF-I levels at week 8 . It was increased to $120 \mathrm{mg} / 4$ weeks if $\mathrm{GH}>2.5 \mu \mathrm{g} / \mathrm{l}$ or if IGF-I was above the age-adjusted normal range. It was reduced to $60 \mathrm{mg} / 4$ weeks if mean $\mathrm{GH}<1 \mu \mathrm{g} / \mathrm{l}$ and IGF-I was within the normal range. If the values did not fall within these ranges, the dose remained unchanged at $90 \mathrm{mg}$.

Results: After 24 weeks of treatment with L-Autogel (final doses $60 \mathrm{mg}$ in 3 patients, $90 \mathrm{mg}$ in 4 patients and $120 \mathrm{mg}$ in 18 patients), mean serum GH $(2.9 \pm 2.4 \mu \mathrm{g} / \mathrm{l})$ and IGF-I concentrations $(332 \pm 193 \mu \mathrm{g} / \mathrm{l})$ remained statistically unchanged when compared with baseline values under octreotide LAR (GH 2.4 $\pm 1.8 \mu \mathrm{g} / \mathrm{l}$ and IGF-I $337 \pm 201 \mu \mathrm{g} / \mathrm{l}$, non significant (NS)). There was a significant improvement of the acromegalic symptom score over the study period, from $4.8 \pm 3.4$ to $2.8 \pm 2.5(P<0.001)$ and a small but significant reduction in the residual pituitary tumour volume $(P<0.05)$. Local side-effects were observed less frequently and no technical problems were encountered with the L-Autogel injections, as opposed to treatment with octreotide LAR (60 difficult injections/150 $(P<0.001))$.

Conclusions: L-Autogel appears to be as effective as octreotide LAR in lowering GH and IGF-I concentrations in acromegalic patients. This treatment was also well tolerated by the patients, giving fewer local side-effects and technical problems with injections. These advantages may improve the long-term acceptability of medical treatment in acromegaly.
\end{abstract}

European Journal of Endocrinology 151 317-324

\section{Introduction}

Acromegaly is a rare but serious disease usually resulting from growth hormone (GH) hypersecretion by a pituitary adenoma (1). Transsphenoidal surgery remains the first choice therapy in most patients, resulting in 'disease cure' in $80-90 \%$ of microadenomas, but in only $30-50 \%$ of macroadenomas $(1,2)$. Pituitary radiotherapy can be used as an adjuvant treatment, but it may take 5-10 years to lower GH to acceptable levels and insulin-like growth factor (IGF-I) is normalized only in a minority of patients $(3,4)$. Several medical therapies are also available, including dopamine agonists, somatostatin analogues and a recently developed GH receptor antagonist (5). Among dopamine agonists, cabergoline is well tolerated, but has limited efficacy, being mostly effective in mixed $\mathrm{GH} /$ prolactin secreting tumours and in GH-secreting adenomas where pretreatment levels of GH and IGF-I are low (6). Several somatostatin analogue preparations are currently used as primary or secondary treatment for acromegaly, in particular two long-acting depot formulations, octreotide long-acting repeatable (LAR) and lanreotide slow release (SR). They have both been shown to be safe and effective, normalizing serum IGF-I levels in up to $60 \%$ of cases $(7-11)$. In comparative studies, some investigators have found no significant differences between the two treatments $(12,13)$ although other authors have reported a slight advantage in favour of octreotide LAR (14-16). More recently, the GH receptor antagonist pegvisomant has been reported to be highly effective in normalizing IGF-I concentrations in most 
acromegalics, but this treatment requires daily subcutaneous injections and does not act directly on the pituitary tumour $(5,17)$. The limitations of all currently available medical therapies justifies the ongoing search for somatostatin receptor agonists that are more effective and easy to use.

L-Autogel is a new, long-acting aqueous preparation of lanreotide which is administered by deep subcutaneous injections every 4 weeks and provides a consistent drug release over this time period $(18,19)$. A previous clinical study has shown that this new formulation is at least as effective and well tolerated as lanreotide SR given every 10-14 days intramuscularly (18). The ease of monthly injections may also improve the acceptability of medical treatment to patients requiring long-term somatostatin analogue therapy.

The aim of this study was to assess the efficacy and tolerability of L-Autogel in acromegalic patients previously treated with octreotide LAR for a minimum of six months and to compare the outcomes of treatment with both drugs.

\section{Patients and methods}

\section{Patients}

Twenty-five patients with active acromegaly were included in this study (Tables 1 and 2). Initial diagnosis was based on typical clinical features; failure of GH to suppress below $2 \mu \mathrm{g} / \mathrm{l}$ during an oral glucose tolerance test and elevated serum IGF-I levels above sex- and agematched values.

All patients were treated with octreotide LAR at a fixed dose over at least six months before entering the study $(20 \mathrm{mg}$ in 13 patients, $30 \mathrm{mg}$ in 11 patients and $40 \mathrm{mg}$ in 1 patient). Five patients were also receiving cabergoline treatment, which was not changed over the study period. At the time of diagnosis, 23 patients had a macroadenoma and two had a microadenoma. Thirteen patients had undergone pituitary surgery, four had received conventional radiotherapy and one

Table 1 Characteristics of the study population at baseline.

\begin{tabular}{lccc}
\hline Characteristics & $\boldsymbol{n}$ & Mean \pm s.D. & Range \\
\hline Age (years) & 25 & $51 \pm 12$ & $23-83$ \\
$\mathrm{BMI}\left(\mathrm{kg} / \mathrm{m}^{2}\right)$ & 25 & $29.4 \pm 5.3$ & $20.8 \pm 46.8$ \\
$\mathrm{sBP}(\mathrm{mmHg})$ & 25 & $125 \pm 14$ & $95-160$ \\
$\mathrm{dBP}(\mathrm{mmHg})$ & 25 & $78 \pm 9$ & $65-95$ \\
Time since diagnosis of & 25 & $8 \pm 1$ & $2-21$ \\
$\quad$ acromegaly (years) & & & \\
$\begin{array}{l}\text { Time since previous } \\
\quad \text { surgery (years) }\end{array}$ & $13(52 \%)$ & $7 \pm 4$ & $2-14$ \\
$\begin{array}{l}\text { Time since previous } \\
\quad \text { radiotherapy (years) }\end{array}$ & $5(20 \%)$ & $9 \pm 7$ & $2-21$ \\
$\begin{array}{l}\text { Duration of octreotide LAR } \\
\quad \text { treatment (months) }\end{array}$ & 25 & $27 \pm 15$ & $8-84$ \\
\hline
\end{tabular}

BMI, body mass index; sBP, systolic blood pressure; dBP, diastolic blood pressure. radiosurgery, at least two years before entering the study. Five patients had partial or complete hypopituitarism and received adequate and stable hormone replacement therapy.

The protocol was approved by the local ethics committees of each study centre and all patients gave written informed consent.

\section{Study protocol (Fig. 1)}

The trial was a prospective, open label, multicentre, within-subject controlled study. All patients were switched from octreotide LAR (Sandostatin LAR (Novartis Pharma AG)) to L-Autogel (Somatuline Autogel (Ipsen Biotech)) injections without a wash-out period. For the first three injections (weeks 0, 4 and 8) $90 \mathrm{mg}$ of L-Autogel was administered to all patients, irrespective of their previous LAR dose. For the fourth injection (week 12) the dose of l-Autogel was determined from the fasting serum GH and IGF-I levels at week 8 . This titrated dose was maintained throughout the remainder of the study. If the mean GH concentration (from 3 consecutive samples taken at $30 \mathrm{~min}$ intervals) was greater than $2.5 \mu \mathrm{g} / \mathrm{l}$, or if IGF-I was above the age-adjusted normal range, the dose of L-Autogel was increased to $120 \mathrm{mg}$. If mean GH concentration was less than $1 \mu \mathrm{g} / \mathrm{l}$ and IGF-I was normal the dose was decreased to $60 \mathrm{mg}$. If the $\mathrm{GH}$ and IGF-I levels did not fall within these bands, the dose was unchanged.

\section{GH and IGF-I measurements}

Serum GH and IGF-I concentrations were measured in a central laboratory (St Luc University Hospital, Brussels, Belgium) by automated, two-site chemiluminescence immunoassays (Nichols Advantage IGF-I Assay, Nichols Advantage HGH Assay; Nichols Institute Diagnostics, San Juan Capistrano, CA, USA) (20). The calculated sensitivity of the $\mathrm{GH}$ assay was $0.1 \mu \mathrm{g} / \mathrm{l}$ and the intra- and interassay coefficients of variation were $4.8 \%$ and $5.8 \%$, respectively. The sensitivity of the IGF-I assay was $6 \mu \mathrm{g} / \mathrm{l}$ and the intra-assay and interassay coefficients of variation were $5.2 \%$ and $5.7 \%$, respectively. The normal range of IGF-I values was determined as follows: $113-463 \mu \mathrm{g} / \mathrm{l}(22-25$ years); $125-379 \mu \mathrm{g} / \mathrm{l}$ (25-30 years); $114-316 \mu \mathrm{g} / \mathrm{l}$ (30-35 years); $108-301 \mu \mathrm{g} / \mathrm{l} \quad(35-40$ years); $101-279 \mu \mathrm{g} / \mathrm{l}$ (40-50 years); $92-253 \mu \mathrm{g} / \mathrm{l}(50-60$ years) and $83-230 \mu \mathrm{g} / \mathrm{l}(60-80$ years $)$.

\section{Symptoms of acromegaly}

Five signs and symptoms of acromegaly (headache, perspiration, asthenia, swelling of extremities and joint pain) were self-evaluated at baseline and after 6 months of treatment, using a four-point rating scale (0, absent; 1 , mild; 2 , moderate; 3 , severe). A symptom 
Table 2 Individual characteristics of the patients before treatment with somatostatin analogues (SSA), at study entry (V0) and after six months of treatment with I-Autogel (V6).

\begin{tabular}{|c|c|c|c|c|c|c|c|c|c|c|}
\hline \multirow[b]{2}{*}{$\begin{array}{l}\text { Patient } \\
\text { no. }\end{array}$} & \multirow[b]{2}{*}{ Gender } & \multirow[b]{2}{*}{ Age } & \multicolumn{2}{|c|}{$\begin{array}{l}\text { Before treatment } \\
\text { with SSA }\end{array}$} & \multirow[b]{2}{*}{$\begin{array}{c}\text { Time from } \\
\text { Surgery to V0 }\end{array}$} & \multirow[b]{2}{*}{$\begin{array}{c}\text { Time from } \\
\text { Rx-therapy to Vo }\end{array}$} & \multicolumn{2}{|c|}{ Vo } & \multicolumn{2}{|l|}{ V6 } \\
\hline & & & $\begin{array}{c}\mathrm{GH} \\
(\mu \mathrm{g} / \mathrm{l})\end{array}$ & $\begin{array}{c}\text { IGF-I } \\
\left(\mu \mathrm{g} / \mathrm{l} \text { or } \mathrm{U} / \mathrm{ml}^{*}\right)\end{array}$ & & & $\begin{array}{c}\text { Mean } \mathrm{GH}^{\S} \\
(\mu \mathrm{g} / \mathrm{l})\end{array}$ & $\begin{array}{l}\text { IGF-I } \\
(\mu \mathrm{g} / \mathrm{l})\end{array}$ & $\begin{array}{c}\text { Mean } \mathrm{GH}^{\S} \\
(\mu \mathrm{g} / \mathrm{l})\end{array}$ & $\begin{array}{l}\text { IGF-I } \\
(\mu \mathrm{g} / \mathrm{l})\end{array}$ \\
\hline 1 & M & 76 & 38.5 & 871 & & & 2.4 & 167 & 5.2 & 206 \\
\hline 2 & $\mathrm{~F}$ & 59 & 10.5 & 537 & & & 2.3 & 156 & 2.7 & 206 \\
\hline 3 & M & 51 & 30 & 803 & & & 1.6 & 298 & 2.6 & 254 \\
\hline 4 & $\mathrm{~F}$ & 59 & 4.9 & 350 & 5 & & 1.7 & 276 & 1.8 & 293 \\
\hline 5 & $\mathrm{~F}$ & 71 & 18 & 686 & & 21 & 5.1 & 191 & 1.2 & 178 \\
\hline 6 & M & 52 & NA & 416 & 5 & & 0.2 & 224 & 0.2 & 186 \\
\hline 7 & $\mathrm{~F}$ & 36 & 75 & 2141 & 6 & 6 & 5.0 & 294 & 6.1 & 358 \\
\hline 8 & M & 38 & 36 & 1500 & & & 0.2 & 207 & 0.2 & 194 \\
\hline 9 & $\mathrm{~F}$ & 54 & 17 & 652 & & & 1.3 & 442 & 1.7 & 361 \\
\hline 10 & M & 55 & 45 & 880 & & & 0.7 & 144 & 0.6 & 166 \\
\hline 11 & $\mathrm{~F}$ & 34 & 33 & 919 & 6 & 6 & 4.0 & 243 & 2.6 & 249 \\
\hline 12 & M & 55 & 15.5 & 609 & 14 & & 7.1 & 808 & 4.8 & 760 \\
\hline 13 & $\mathrm{~F}$ & 43 & 25 & 790 & 4 & & 2.3 & 559 & 2.9 & 570 \\
\hline 14 & $\mathrm{~F}$ & 64 & 19 & $6.6^{\star}$ & & & 0.4 & 104 & 2.2 & 143 \\
\hline 15 & $\mathrm{~F}$ & 51 & 16.5 & $5.7^{*}$ & 13 & & 3.1 & 331 & 7.2 & 411 \\
\hline 16 & $\mathrm{~F}$ & 58 & 40 & $8.6^{*}$ & 12 & 12 & 1.6 & 319 & 0.9 & 271 \\
\hline 17 & M & 33 & 37 & 1400 & & & 3.0 & 557 & 4.4 & 610 \\
\hline 18 & $\mathrm{~F}$ & 23 & 111 & 936 & & & 5.0 & 308 & 10.4 & 373 \\
\hline 19 & M & 83 & 6.5 & 948 & & & 4.7 & 749 & 2.4 & 420 \\
\hline 20 & M & 49 & 9.3 & 1365 & 2 & & 3.3 & 784 & 3.5 & 898 \\
\hline 21 & M & 48 & 20 & 600 & 12 & & 1.6 & 314 & 2.7 & 325 \\
\hline 22 & M & 42 & 17.8 & 1011 & 4 & 2 & 1.7 & 301 & 3.0 & 268 \\
\hline 23 & M & 43 & 24.2 & $8.4^{\star}$ & 4 & & 0.1 & 187 & 0.3 & 148 \\
\hline 24 & M & 34 & 71 & $4.0^{*}$ & 4 & & 1.9 & 308 & 2.4 & 272 \\
\hline 25 & $\mathrm{~F}$ & 68 & 3.9 & $4.0^{*}$ & & & 0.6 & 160 & 0.8 & 190 \\
\hline
\end{tabular}

NA, not available.

* Concentrations determined by RIA on unextracted samples.

${ }^{\S}$ Mean of the three consecutive values at 30 minute-intervals.

score was derived from the sum of all points recorded in every patient (maximum score of 15 ).

\section{Tolerability and injection site reactions}

General adverse events were recorded throughout the study. Symptoms and signs at the injection site were recorded after the last injection of octreotide LAR, visit $O(\mathrm{VO})$ and l-Autogel, visit 6 (V6) and rated

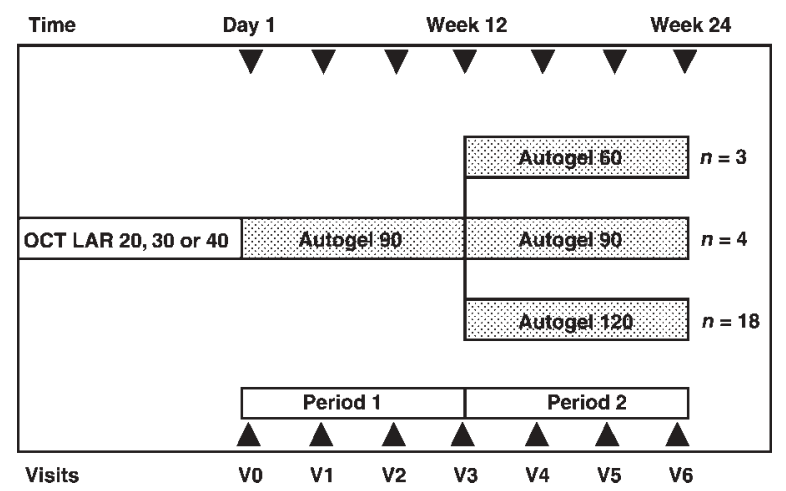

Figure 1 Flow chart of the study. OCT LAR, octreotide LAR $(20 \mathrm{mg}, 30 \mathrm{mg}$ or $40 \mathrm{mg}$ ); Autogel, L-Autogel $(60 \mathrm{mg}, 90 \mathrm{mg}$ or $120 \mathrm{mg})$. using a scale of 0 to 3 ( 0 , none; 1 , mild; 2 , moderate; 3 , severe). At first and last visits the number of technically difficult injections that occurred over the previous 24 weeks of treatment was estimated for each analogue using patients' retrospective recall. At the end of the study, patients and nurses were also asked about their preference regarding both treatment modalities.

\section{Other parameters}

Blood samples for haematology and biochemistry analysis were taken at VO, and after 3 and 6 months of treatment. Ultrasound examination of the gallbladder was performed at baseline and at the end of the study in 22 patients. Three patients had undergone previous cholecystectomy. Pituitary imaging was also performed at baseline and at the last evaluation. Measurements of pituitary tumour diameters were taken whenever a residual pituitary tumour was present. The volume of the tumour was calculated using the mathematical formula of a rotating ellipsoid (21).

\section{Statistics}

Continuous, normally distributed variables were analysed using an ANOVA model to compare values 
recorded at VO and V6 in each patient. For discrete variables or for continuous variables, which even after log-transformation grossly violated the normality assumptions for ANOVA analysis, the Wilcoxon's signed-rank test was performed on the recorded differences between V6 and V0. Proportions were compared using the Fisher's exact test.

\section{Results}

All 25 patients completed the study and Table 2 shows their individual characteristics before any treatment with a somatostatin analogue (SSA) at VO and after six months of treatment with L-Autogel (V6). High serum GH and/or IGF-I concentrations were observed prior to the start of SSA therapy in all patients. Average body weight and systolic and diastolic blood pressure did not change significantly during the study period (data not shown). In 18 patients, the L-Autogel dose was increased to $120 \mathrm{mg} / 4$ weeks. In 4 patients, the dose remained unchanged at $90 \mathrm{mg} / 4$ weeks, while it was reduced to $60 \mathrm{mg} / 4$ weeks in 3 patients. Among the 13 patients previously treated with octreotide LAR at a dose of $20 \mathrm{mg}, 3$ received a titrated dose of $60 \mathrm{mg}, 4$ received $90 \mathrm{mg}$ and 6 received $120 \mathrm{mg}$ of L-Autogel. All 12 patients on 30 or $40 \mathrm{mg}$ octreotide LAR received $120 \mathrm{mg}$ L-Autogel after dose titration.

\section{GH and IGF-I}

The mean $\mathrm{GH}$ value in the 25 patients at VO was $2.4 \pm 1.8 \mu \mathrm{g} / \mathrm{l}$. It increased slightly to $2.9 \pm 2.4 \mu \mathrm{g} / \mathrm{l}$ (mean \pm S.D.) after 24 weeks of L-Autogel treatment, but this variation was not statistically significant. There was also no significant change in serum IGF-I concentrations between V0 and V6 (337 $\pm 201 \mu \mathrm{g} / \mathrm{l}$ vs. $332 \pm 193 \mu \mathrm{g} / \mathrm{l}$, respectively; mean \pm S.D.) (Tables 2 and 3$)$.

Table 3 Serum GH and IGF-I concentrations and side effects and tolerability of treatments with octreotide LAR and L-Autogel in the 25 acromegalic patients.

\begin{tabular}{|c|c|c|c|}
\hline & Octreotide LAR & L-Autogel & $\boldsymbol{P}$ \\
\hline Mean GH $(\mu \mathrm{g} / l)^{\S}$ & $2.4 \pm 1.8$ & $2.9 \pm 2.4$ & $N S$ \\
\hline IGF-I $(\mu \mathrm{g} / \mathrm{I})^{\S}$ & $337 \pm 202$ & $332 \pm 193$ & NS \\
\hline Glucose $(\mathrm{mmol} / \mathrm{l})^{\S}$ & $6.3 \pm 1.5$ & $6.4 \pm 1.8$ & NS \\
\hline $\mathrm{HbA}_{1} \mathrm{c}(\%)^{\S}$ & $6.1 \pm 0.9$ & $6.1 \pm 0.9$ & NS \\
\hline Local side effects & & & $<0.001$ \\
\hline Erythema* & 1 & 1 & \\
\hline Pain* & 19 & 3 & \\
\hline Swelling* & 9 & 2 & \\
\hline General side effects & & & $N S$ \\
\hline Nausea* & 3 & 2 & \\
\hline Diarrhoea* & 2 & 4 & \\
\hline Abdominal discomfort* & 3 & 2 & \\
\hline
\end{tabular}

*Number of patients.

$\S_{\text {Mean } \pm \text { S.D. }}$
Under octreotide LAR treatment, a mean GH level of less than $2.5 \mu \mathrm{g} / \mathrm{l}$ was observed in 16 patients $(64 \%)$ (Table 4). After the sixth L-Autogel injection, the number of patients with a $\mathrm{GH}$ concentration below $2.5 \mu \mathrm{g} / \mathrm{l}$ was reduced to $12(48 \%)$, although this difference was not statistically significant. Six out of 16 patients with normal GH values under octreotide LAR treatment showed slightly higher GH levels after the 24 weeks of L-Autogel therapy, while two out of the nine previously uncontrolled patients normalized their GH levels after switching medication. The remaining 17 patients showed no changes in their GH status: 10 patients had serum GH levels below $2.5 \mu \mathrm{g} / \mathrm{l}$ whilst in seven patients these levels remained above $2.5 \mu \mathrm{g} / \mathrm{l}$, whichever medication used (Fig. 2A and B).

In slight discordance with the $\mathrm{GH}$ response, the number of patients with a normal IGF-I value was identical under both octreotide LAR and L-Autogel treatments $(13 / 25,52 \%)$ (Table 4). Twelve patients were well controlled by both drugs. One patient had a normal IGF-I value during octreotide LAR $40 \mathrm{mg}$ but showed an elevated value under lanreotide Autogel at the highest dose of $120 \mathrm{mg}$. The opposite finding was observed in one other patient, not controlled during octreotide LAR $30 \mathrm{mg}$, but normalizing IGF-I after LAutogel $120 \mathrm{mg}$ (Fig. $3 \mathrm{~A}$ and B). The changes in serum GH and IGF-I concentrations after the switch from one analogue to the other were not influenced by the previous dose of octreotide LAR (Figs 2 and 3, A vs B, NS).

\section{Symptoms of acromegaly and tumour size}

During L-Autogel therapy, the mean symptom score decreased from $4.8 \pm 3.4$ at V0 to $2.8 \pm 2.5$ at V6 $(P<0.001)$ and this reduction was independent of the dose of octreotide LAR. When patients were grouped according to their IGF-I values at VO, only the subgroup of patients with abnormally high IGF-I values showed a significant reduction in their symptom score $(P<0.01)$ between V0 and V6.

At baseline MRI examination, the mean volume of the tumour was $1416 \pm 2405 \mathrm{~mm}^{3}$ (20 patients) and it decreased slightly, but significantly, to $1218 \pm 2215 \mathrm{~mm}^{3}$ after 6 months $(P<0.05)$.

\section{Side effects and tolerability}

General side effects, including nausea, diarrhoea and abdominal discomfort, were reported by a minority of patients with no significant difference between octreotide LAR and L-Autogel treatment (Table 3). In contrast, local side effects were observed less frequently after the last L-Autogel injection than after the last octreotide LAR injection $(P<0.001)$. Nineteen patients reported technical problems encountered by the nurse during at least one of the last six octreotide LAR injections (60 injections estimated as technically 
Table 4 Patients with normal GH and IGF-I on different doses of octreotide LAR and L-Autogel.

\begin{tabular}{lccccccccc}
\hline & \multicolumn{3}{c}{ Octreotide LAR } & & \multicolumn{3}{c}{ L-Autogel } \\
\cline { 2 - 3 } & $20 \mathrm{mg}$ & $30 \mathrm{mg}$ & $40 \mathrm{mg}$ & Either dose & $60 \mathrm{mg}$ & $90 \mathrm{mg}$ & $120 \mathrm{mg}$ & Either dose & $\boldsymbol{P}^{*}$ \\
\hline $\begin{array}{l}\text { Number of patients with mean } \\
\text { GH } \leq 2.5 \mu \mathrm{g} / \mathrm{l}(\%)\end{array}$ & $12 / 13(92 \%)$ & $4 / 11(36 \%)$ & $0 / 1(0 \%)$ & $16 / 25(64 \%)$ & $3 / 3(100 \%)$ & $3 / 4(75 \%)$ & $6 / 18(33 \%)$ & $12 / 25(48 \%)$ & $N S$ \\
$\begin{array}{l}\text { Number of patients with normal } \\
\text { IGF-I (\%) }\end{array}$ & $9 / 13(69 \%)$ & $3 / 11(27 \%)$ & $1 / 1(100 \%)$ & $13 / 25(52 \%)$ & $3 / 3(100 \%)$ & $3 / 4(75 \%)$ & $7 / 18(39 \%)$ & $13 / 25(52 \%)$ & $N S$ \\
\hline
\end{tabular}

* $P$ values refer to the comparison between either dose of octreotide LAR and either dose of L-Autogel.

difficult from a total of 150). In contrast, no technical problems were observed during any of the L-Autogel injections $(P<0.001)$.

There were no changes in fasting glucose or HbAlc values between V0 and V6 (Table 3). Ten of 22 patients had gallstones or sludge at baseline and these ultrasonographic abnormalities remained unchanged over the study period.
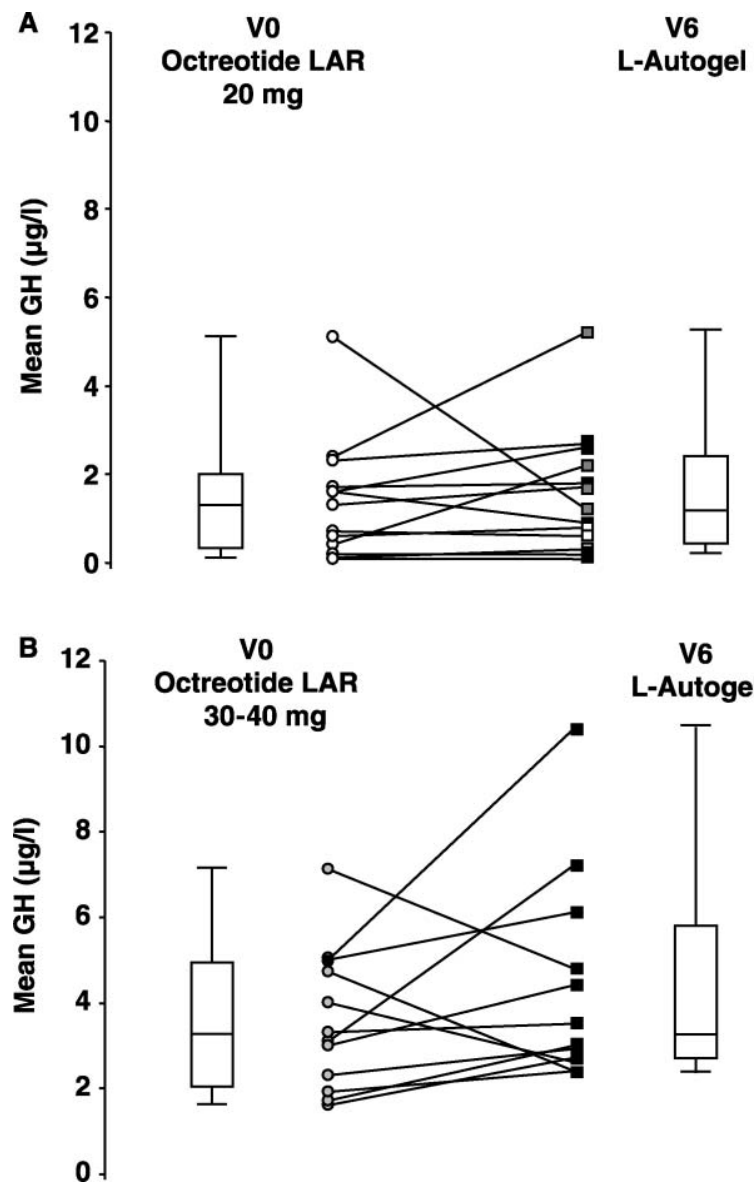

V6

L-Autogel

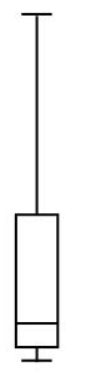

Figure 2 Serum mean GH concentrations at V0, following octreotide LAR $20 \mathrm{mg}$ (panel A, $n=13$ ) or octreotide LAR $30-40 \mathrm{mg}$ (panel B, $n=12,30 \mathrm{mg} \bullet ; 40 \mathrm{mg} \bullet$ ) and at V6, after the 6th injection of L-Autogel (60 mg $\square ; 90 \mathrm{mg} \mathrm{m} ; 120 \mathrm{mg} \mathbf{}$ ). Data are presented as medians, the interquartile range and the 5th and 95th percentiles.

\section{Discussion}

We examined the effects of L-Autogel in acromegalic patients previously treated with octreotide LAR, in order to compare the efficacy and tolerability of both treatments. There are, at present, only a few papers examining the effects of L-Autogel in acromegaly $(18,19)$ and a larger number on the effects of octreotide
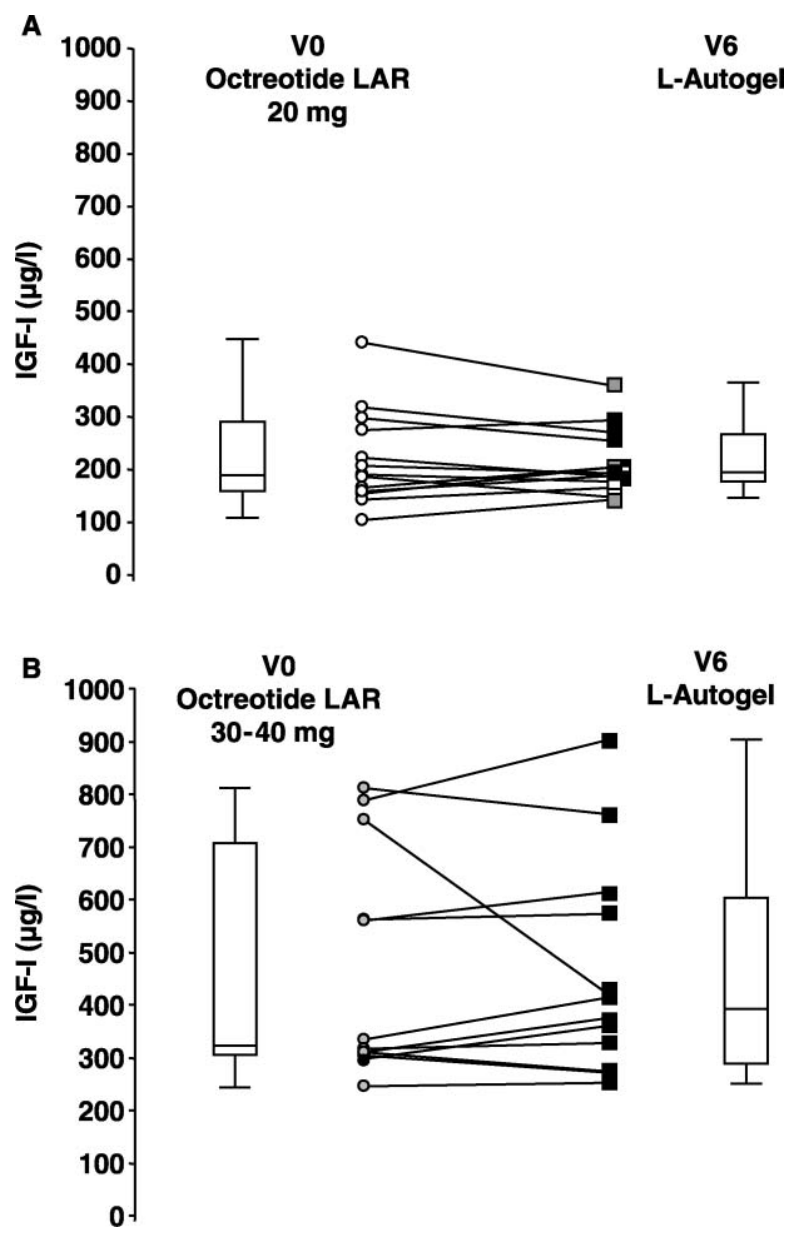

Figure 3 Serum IGF-I concentrations at V0, following octreotide LAR $20 \mathrm{mg}$ (panel A, $n=13$, o) or octreotide LAR $30-40 \mathrm{mg}$ (panel B, $n=12,30 \mathrm{mg} \bullet ; 40 \mathrm{mg} \bullet$ ) and at V6, after the 6th injection of L-Autogel (60 mg $\square ; 90 \mathrm{mg} \approx ; 120 \mathrm{mg}$ ). Data are presented as medians, the interquartile range and the 5 th and 95 th percentiles. 
LAR $(7,14,16,22-25)$. The present study shows that both somatostatin analogues were well tolerated and similarly effective in the treatment of acromegaly, with minor differences that may alternatively favour one or the other depot formulation. Two recent studies $(26,27)$ have also compared the effects of octreotide LAR and L-Autogel in smaller numbers of acromegalic patients. In a group of 10 patients, in which the disease was well-controlled, switching from LAR $20 \mathrm{mg}$ to L-Autogel 60-120 mg/4 weeks resulted in similar effects on GH levels, but in a slightly greater reduction of IGF-I after 28 weeks (26), while in another recent 12-month study of seven patients with a good responsiveness to octreotide, no difference in GH and IGF-I suppression was observed between the two long-acting analogues (27). Using a GH target value below $2.5 \mu \mathrm{g} / \mathrm{l}$, we demonstrated that a similar control of $\mathrm{GH}$ secretion can be obtained with both octreotide LAR and L-Autogel injections over a treatment period of 6 months in a larger cohort of acromegalics, including patients with severe disease. Indeed, after the switch from octreotide to LAutogel depot formulation there was no statistically significant difference in mean GH values nor in the number of patients with a mean GH below $2.5 \mu \mathrm{g} / \mathrm{l}$, although a slight decrease was observed from $64 \%$ of patients treated with octreotide LAR to $48 \%$ after L-Autogel treatment. Similar results have been observed in previous studies $(18,28)$.

Normalization of serum IGF-I has also been shown to correlate with a normalization of the standard mortality rate $(29,30)$. In this study, we showed that a normal age-adjusted IGF-I concentration was obtained in $52 \%$ of the patients receiving either treatment. This figure falls within the range of normalization rate found in previous studies $(18,25)$. It is worthy of note that in about $40 \%$ of patients, adequately controlled hormone levels are not achieved with the currently available somatostatin analogues, indicating a need for other therapeutic tools such as GH-receptor antagonists or newly-designed analogues with higher affinity for somatostatin receptor subtypes 2 and 5 (31).

As in several other studies, we not only observed different percentages of patients normalizing GH and IGF-I levels but also a discrepancy between individual $\mathrm{GH}$ and IGF-I responses. There is ongoing debate about the correlation (or lack of) between serum GH and IGF-I levels in individual patients treated for acromegaly, and a number of mechanisms have been proposed to explain these discrepancies $(32,33)$. In our study we also observed some discrepancies between the changes in GH and IGF-I after the switch to L-Autogel, with a few patients being well controlled in terms of IGF-I but not in terms of GH. This could be due to slight differences in the affinity of both drugs for the somatostatin receptor subtypes (34) or in the pharmacokinetic profiles of the two drugs. In this regard, it appears that at least 6 months may be required for steady state to be reached with L-Autogel treatment in some patients (26). Lastly, a possible direct effect of L-Autogel on IGF-I secretion, independent of GH levels, cannot be firmly excluded.

A nearly similar control of $\mathrm{GH}$ hypersecretion by both somatostatin analogues was observed in this study. To achieve this, a significant proportion of patients $(6 / 13)$ previously treated with the lowest dose of octreotide LAR $(20 \mathrm{mg} / 4$ weeks $)$ had to be switched to the highest dose of L-Autogel (120 mg/ 4 weeks), and all patients treated with 30 or $40 \mathrm{mg}$ of octreotide LAR were switched to the $120 \mathrm{mg}$ L-Autogel dose. This could be explained in part by a bias in the selection criteria, since patients receiving octreotide LAR treatment had been selected on the basis of their response to subcutaneous octreotide injections. In addition, the titration criteria that we used for L-Autogel could not be applied for octreotide LAR, since patients were already treated with this analogue at study entry. Therefore, it is difficult to strictly compare the relative dose equivalence of the two drugs within the frame of the present study. Nevertheless, it seems that a majority of patients switched from $30 \mathrm{mg}$ octreotide LAR to $120 \mathrm{mg}$ L-Autogel will have roughly equivalent disease control.

The clinical symptoms of acromegaly were significantly improved after the switch from octreotide LAR to L-Autogel. A decrease in the mean symptom score was observed across the whole group of patients between V0 and V6. In patients with initially uncontrolled disease on the basis of IGF-I values this was particularly apparent. Since the baseline IGF-I status did not influence the outcome of mean $\mathrm{GH}$ levels, we suggest that L-Autogel treatment can control clinical symptoms of acromegaly irrespective of $\mathrm{GH}$ levels. This has indeed been previously reported for lanreotide SR $(8,35)$ and for octreotide $\operatorname{LAR}(23,24)$. Interpretation of our data is, however, limited by the nature of our open, one-way protocol. A strict comparison of the efficacy of the two somatostatin analogues on the symptom score would require a randomised, doubleblind, cross-over study.

The effects of L-Autogel on tumour size are also difficult to interpret as most of the patients had had prior surgery and/or radiotherapy in addition to octreotide LAR treatment. We observed a slight but significant decrease in tumour volume over the 6 month study period, yet it would be unwise to attribute this effect to the change in treatment since we do not know whether the tumour volume was stable or still decreasing before the switch from one analogue to the other. In fact, the effects of any treatment on tumour size should be evaluated in de novo patients or after a longer period of treatment $(25,36,37)$.

Both treatments were generally well tolerated and none of the patients had to be withdrawn from the study, partly because they were already treated with an analogue at the start of the study. We did not observe any change of glycaemic control, in agreement 
with Caron et al. (18). Only a few patients reported systemic side effects after the last octreotide LAR injection, reflecting those seen in previous studies $(7,23)$. The frequency of reported general side effects remained unchanged throughout the course of the study. One important adverse event during long-term somatostatin analogue therapy is an increased tendency towards gallstone formation. This complication was indeed observed at baseline in $45 \%$ of our patients, but no further development of gallstones or sludge was found after six L-Autogel injections.

Immediate local tolerability at the injection site was significantly better with L-Autogel injections. Mild to moderate pain at the injection site was reported by $76 \%$ of the patients for octreotide LAR, a percentage higher than those found in previous studies $(7,38)$. In contrast, only $12 \%$ of patients complained of local pain after the sixth L-Autogel injection, as also reported by Caron et al. (18). As a consequence, when patients were asked their preference about treatment, the majority (17/25) chose L-Autogel and only two of them preferred octreotide LAR. L-Autogel was easier to inject and no technical problems were encountered during any of the six injections in any patient. This was not the case for octreotide LAR, since a majority of the patients recalled the occurrence of minor or major technical problems for at least one out of the six last injections of LAR, even though injections were given by experienced paramedical staff. It is likely that this was related to the known differences in the drug formulation, with L-Autogel administered as a stable gel by deep subcutaneous injections of small volume $(0.2-0.4 \mathrm{ml})$ from a prefilled syringe, as opposed to octreotide LAR which needs a prior reconstitution from a solid phase into a $2-3 \mathrm{ml}$ suspension of microparticles.

In conclusion, this open label, multicentre switch study shows that L-Autogel is an effective, well tolerated and safe therapy for acromegalic patients. When compared with a prior octreotide LAR treatment, 4-weekly injections of L-Autogel seem to be equally effective in maintaining adequate mean GH and IGF-I concentrations. This new formulation was also very well accepted by the patients, giving fewer local side effects or technical problems with the injections. These advantages could increase the compliance of acromegalic patients to long-term medical therapy.

\section{Acknowledgements}

The authors wish to thank the Ipsen company for generously supplying the study medication L-Autogel.

\section{References}

1 Melmed S. Acromegaly. In The Pituitary, 2nd edn, ch 11, pp 419-454. Ed. S Melmed. Massachusetts: Blackwell Science Inc., 2002.
2 Fahlbusch R, Honegger J \& Buchfelder M. Surgical management of acromegaly. Endocrinology and Metabolism Clinics of North America 199221 669-692.

3 Powell JS, Wardlaw SL, Post KD \& Freda PU. Outcome of radiotherapy for acromegaly using normalization of insulin-like growth factor I to define cure. Journal of Clinical Endocrinology and Metabolism 200085 2068-2071.

4 Epaminonda P, Porretti S, Cappiello V, Beck-Peccoz P, Faglia G \& Arosio M. Efficacy of radiotherapy in normalizing serum IGF-I, acid-labile subunit (ALS) and IGFBP-3 levels in acromegaly. Clinical Endocrinology 200155 183-189.

5 Clemmons DR, Chihara K, Freda PU, Ho KK, Klibanski A, Melmed S, Shalet SM, Strasburger CJ, Trainer PJ \& Thorner MO. Optimizing control of acromegaly: integrating a growth hormone receptor antagonist into the treatment algorithm. Journal of Clinical Endocrinology and Metabolism $2003 \mathbf{8 8} 4759-4767$.

6 Abs R, Verhelst J, Maiter D, Van Acker K, Nobels F, Coolens JL, Mahler C \& Beckers A. Cabergoline in the treatment of acromegaly: a study in 64 patients. Journal of Clinical Endocrinology and Metabolism $1998 \mathbf{8 3} 374-378$.

7 Stewart PM, Kane KF, Stewart SE, Lancranjan I \& Sheppard MC. Depot long-acting somatostatin analog (Sandostatin-LAR) is an effective treatment for acromegaly. Journal of Clinical Endocrinology and Metabolism $1995 \mathbf{8 0} 3267-3272$.

8 Giusti M, Gussoni G, Cuttica CM \& Giordano G. Effectiveness and tolerability of slow release lanreotide treatment in active acromegaly: six-month report on an Italian multicenter study. Italian Multicenter Slow Release Lanreotide Study Group. Journal of Clinical Endocrinology and Metabolism 199681 2089-2097.

9 Caron P, Morange-Ramos I, Cogne M \& Jaquet P. Three year follow-up of acromegalic patients treated with intramuscular slow-release lanreotide. Journal of Clinical Endocrinology and Metabolism 199782 18-22.

10 Lancranjan I \& Atkinson AB. Results of a European multicentre study with Sandostatin LAR in acromegalic patients. Sandostatin LAR Group. Pituitary 19991 105-114.

11 Verhelst JA, Pedroncelli AM, Abs R, Montini M, Vandeweghe MV, Albani G, Maiter D, Pagani MD, Legros JJ, Gianola D, Bex M, Poppe K, Mockel J \& Pagani G. Slow-release lanreotide in the treatment of acromegaly: a study in 66 patients. European Journal of Endocrinology $2000143577-584$.

12 Kendall-Taylor P, Miller M, Gebbie J, Turner S \& al Maskari M. Long-acting octreotide LAR compared with lanreotide SR in the treatment of acromegaly. Pituitary 20003 61-65.

13 Amato G, Mazziotti G, Rotondi M, Iorio S, Doga M, Sorvillo F et al. Long-term effects of lanreotide SR and octreotide LAR on tumour shrinkage and $\mathrm{GH}$ hypersecretion in patients with previously untreated acromegaly. Clinical Endocrinology 200256 65-71.

14 Turner HE, Vadivale A, Keenan J \& Wass JA. A comparison of lanreotide and octreotide LAR for treatment of acromegaly. Clinical Endocrinology 199951 275-280.

15 Cozzi R, Dallabonzana D, Attanasio R, Barausse M \& Oppizzi G. A comparison between octreotide-LAR and lanreotide-SR in the chronic treatment of acromegaly. European Journal of Endocrinology $1999141267-271$.

16 Chanson P, Boerlin V, Ajzenberg C, Bachelot Y, Benito P, Bringer J, Caron P, Charbonnel B, Cortet C, Delemer B, Escobar-Jimenez F, Foubert L, Gaztambide S, Jockenhoevel F, Kuhn JM, Leclere J, Lorcy Y, Perlemuter L, Prestele H, Roger P, Rohmer V, Santen R, Sassolas G, Scherbaum WA, Schopohl J, Torres E, Varela C, Villamil F \& Webb SM. Comparison of octreotide acetate LAR and lanreotide SR in patients with acromegaly. Clinical Endocrinology $200053577-586$.

17 Trainer PJ, Drake WM, Katznelson L, Freda PU, Herman-Bonert V, van der Lely AJ, Dimaraki EV, Stewart PM, Friend KE, Vance ML, Besser GM, Scarlett JA, Thorner MO, Parkinson C, Klibanski A, Powell JS, Barkan AL, Sheppard MC, Malsonado M, Rose DR, Clemmons DR, Johannsson G, Bengtsson BA, Stavrou S, Kleinberg DL, Cook DM, Phillips LS, Bidlingmaier M, Strasburger CJ, Hackett S, Zib K, Bennett WF \& Davis RJ. Treatment of acromegaly with 
the growth hormone-receptor antagonist pegvisomant. New England Journal of Medicine 2000342 1171-1177.

18 Caron P, Beckers A, Cullen DR, Goth MI, Gutt B, Laurberg P, Pico AM, Valimaki M \& Zgliczynski W. Efficacy of the new longacting formulation of lanreotide (lanreotide Autogel) in the management of acromegaly. Journal of Clinical Endocrinology and Metabolism 200287 99-104.

19 Caron P, Bex M, Cullen DR, Feldt-Rasmussen U, Pico Alfonso AM, Pynka S, Racz K, Schopohl J, Tabarin A \& Valimaki MJ. One-year follow-up of patients with acromegaly treated with fixed or titrated doses of lanreotide Autogel. Clinical Endocrinology 2004 $60734-740$.

20 Brabant G, von zur Muhlen A, Wuster C, Ranke MB, Kratzsch J, Kiess W, Ketelslegers JM, Wilhelmsen L, Hulthen L, Saller B, Mattsson A, Wilde J, Schemer R \& Kann P. German KIMS Board. Serum insulin-like growth factor I reference values for an automated chemiluminescence immunoassay system: results from a multicenter study. Hormone Research 200360 53-60.

21 Di Chiro G \& Nelson KB. The volume of the sella turcica. American Journal of Radiology 196287 989-1008.

22 Cozzi R, Attanasio R, Montini M, Pagani G, Lasio G, Lodrini S, Barausse M, Albizzi M, Dallabonzana D \& Pedroncelli AM. Fouryear treatment with octreotide-long-acting repeatable in 110 acromegalic patients: predictive value of short-term results? Journal of Clinical Endocrinology and Metabolism 200388 3090-3098.

23 Flogstad AK, Halse J, Bakke S, Lancranjan I, Marbach P, Bruns C \& Jervell J. Sandostatin LAR in acromegalic patients: long-term treatment. Journal of Clinical Endocrinology and Metabolism 1997 $8223-28$.

24 Lancranjan I, Bruns C, Grass P, Jaquet P, Jervell J, Kendall-Taylor P, Lamberts SW, Marbach P, Orskov H, Pagani G, Sheppard M \& Simionescu L. Sandostatin LAR.: a promising therapeutic tool in the management of acromegalic patients. Metabolism $1996 \mathbf{4 5}$ $67-71$.

25 Colao A, Ferone D, Marzullo P, Cappabianca P, Cirillo S, Boerlin V, Lancranjan I \& Lombardi G. Long-term effects of depot longacting somatostatin analog octreotide on hormone levels and tumor mass in acromegaly. Journal of Clinical Endocrinology and Metabolism 2001 86 2779-2786.

26 Ashwell SG, Bevan JS, Edwards OM, Harris MM, Holmes C, Middleton MA \& James RA. The efficacy and safety of lanreotide Autogel in patients with acromegaly previously treated with octreotide LAR. European Journal of Endocrinology $2004150473-480$.

27 Van Thiel SW, Romijn JA, Biermasz NR, Ballieux BE, Frolich M, Smit JW, Corssmit EP, Roelfsema F \& Pereira AM. Octreotide long-acting repeatable and lanreotide Autogel are equally effective in controlling growth hormone secretion in acromegalic patients. European Journal of Endocrinology $2004150489-495$.

28 Freda PU. Somatostatin analogs in acromegaly. Journal of Clinical Endocrinology and Metabolism 200287 3013-3018.

29 Holdaway IM, Rajasoorya RC \& Gamble GD. Factors influencing mortality in acromegaly. Journal of Clinical Endocrinology and Metabolism $200489667-674$.
30 Swearingen B, Barker FG 2nd, Katznelson L, Biller BM, Grinspoon S, Klibanski A, Moayeri N, Black PM \& Zervas NT. Long-term mortality after transsphenoidal surgery and adjunctive therapy for acromegaly. Journal of Clinical Endocrinology and Metabolism 1998 83 3419-3426.

31 Van der Hoek J, de Herder WW, Feelders RA, van der Lely AJ, Uitterlinden P, Boerlin V, Bruns C, Poon KW, Lewis I, Weckbecker G, Krahnke T, Hofland LJ \& Lamberts SW. A single-dose comparison of the acute effects between the new somatostatin analog SOM230 and octreotide in acromegalic patients. Journal of Clinical Endocrinology and Metabolism $200489638-645$.

32 Ho KY \& Weissberger AJ. Characterization of 24-h growth hormone secretion in acromegaly: implications for diagnosis and therapy. Clinical Endocrinology 199441 75-83.

33 Holly JM, Cotterill AM, Jemmott RC, Shears D, al-Othman S, Chard T \& Wass JA. Inter-relations between growth hormone, insulin, insulin-like growth factor-I (IGF-I), IGF-binding protein1 (IGFBP-1) and sex hormone-binding globulin in acromegaly. Clinical Endocrinology $199134275-280$.

34 Bruns C, Lewis I, Briner U, Meno-Tetang G \& Weckbecker G. SOM230: a novel somatostatin peptidomimetic with broad somatotropin release inhibiting factor (SRIF) receptor binding and a unique antisecretory profile. European Journal of Endocrinology $2002146707-716$.

35 Marek J, Hana V, Krsek M, Justova V, Catus F \& Thomas F. Longterm treatment of acromegaly with the slow-release somatostatin analogue lanreotide. European Journal of Endocrinology 1994131 $20-26$.

36 Attanasio R, Baldelli R, Pivonello R, Grottoli S, Bocca L, Gasco V. Giusti M, Tamburrano G, Colao A \& Cozzi R. Lanreotide $60 \mathrm{mg}$, a new long-acting formulation: effectiveness in the chronic treatment of acromegaly. Journal of Clinical Endocrinology and Metabolism $2003 \mathbf{8 8} 5258-5265$.

37 Bevan JS, Atkin SL, Atkinson AB, Bouloux PM, Hanna F, Harris PE, James RA, McConnell M, Roberts GA, Scanlon MF, Stewart PM, Teasdale E, Turner HE, Wass JA \& Wardlaw JM. Primary medical therapy for acromegaly: an open, prospective, multicenter study of the effects of subcutaneous and intramuscular slow-release octreotide on growth hormone, insulin-like growth factor-I, and tumor size. Journal of Clinical Endocrinology and Metabolism 200287 4554-4563.

38 Davies PH, Stewart SE, Lancranjan L, Sheppard MC \& Stewart PM Long-term therapy with long-acting octreotide (Sandostatin-LAR) for the management of acromegaly. Clinical Endocrinology 1998 $48311-316$

Received 19 March 2004

Accepted 7 June 2004 